Solveig Karlsen

UiT Norges arktiske universitet

Magne Olufsen

UiT Norges arktiske universitet

DOI: http://dx.doi.org/10.5617/adno.6441

\title{
To ulike utdanninger for skolens mellomtrinn. Er det samsvar mellom planverk og praksislæreres erfaringer med studentenes kompetanser på 1-7 og 5-10 utdanningene?
}

\section{Sammendrag}

I 2010 ble det ved UiT Norges arktiske universitet startet opp et nasjonalt pilotprosjekt (Pilot i Nord) med 5-årige integrerte masterutdanninger for trinn 17 og 5-10. I denne kvalitative sammenligningsstudien har vi intervjuet åtte praksislcerere på mellomtrinnet (trinn 5-7) med veiledningserfaring fra begge disse utdanningene og undersøkt om de opplever kompetanseforskjeller mellom studentgruppene. For å belyse eventuelle forskjeller, har vi også gjort en sammenligning av utdanningene og en dokumentanalyse av emneplanene for pedagogikkfaget $i$ begge utdanningene. Analysene viser at utdanningene var ulike blant annet når det gjaldt antall og omfang av skolefag og størrelse på pedagogikkfaget. Utdanningen for trinn 1-7 har et sterkt fokus mot pedagogikk og elevkunnskap, mens 5-10 utdanningen fokuserer mer på fag og fagdidaktikk. Praksislcrerne erfarer fra praksisoppleringen at studentene ved 5-10 utdanningen har høyere faglig kompetanse, interesse for og identitet til sine valgte fag sammenlignet studenter fra 1-7 utdanningen. Studentene ved 1-7 utdanningen derimot oppleves å ha noe bedre teoretisk grunnlag i pedagogikk og elevkunnskap, og de fokuserer mer på pedagogiske prinsipper i praksisopplceringen. Praksislcererne erfarer også at det er forskjell i holdninger mellom studentgruppene til å undervise i fag i praksisopplaringen som de ikke har fått undervisning i på campus. Studentene ved 5-10 utdanningen er mer motvillige til dette. Studien viser at det er samsvar mellom oppbygging og innhold i de to utdanningene og hvilke kompetanser praksislcererne erfarer at studentene har. Denne artikkelen er i så måte et bidrag i debatten knyttet til hvordan ulike lcererutdanningsmodeller bidrar til studentenes kompetanser.

Nøkkelord: grunnskolelæererutdanning, læererkompetanser, læererutdanning, praksisopplering, lcererstudenter 


\title{
Two different education programs for upper primary school. Is there correspondence between the curricula and the teacher mentors' experiences with students' knowledge in the 1-7 and 5-10 programs?
}

\begin{abstract}
In 2010 UiT The Arctic University of Norway started two new teacher education programmes as a national pilot. The programmes were five-year integrated masters for grade levels 1-7 and 5-10. In this qualitative study we interviewed eight in-service teachers with experience of mentoring pre-service teachers (PSTs) in these two programmes. We explored the differences in types of knowledge between the two groups of students. To highlight prospective differences, we also compared the two teacher programmes and performed a document analysis of the pedagogy curriculum. The educational programmes had several differences: the grade levels 1-7 programme had higher emphasis on pedagogy and included courses in one more school subject, compared to the 5-10 programme. The latter programme had more emphasis on subject matter and didactic knowledge. The in-service teachers' mentoring experiences revealed that the PSTs in the 5-10 programme had higher subject and didactic knowledge, showed more interest in and identified with their chosen subjects. The PSTs in the 1-7 programme appeared to have a better theoretical base in pedagogy and a greater focus on pedagogical principles in their school practice. The in-service teachers also experienced attitudinal differences between the PST groups when the PSTs were teaching subjects for which they were not formally trained from the campus. The PSTs in the 5-10 programme were more reluctant to do this. This study shows that there is consistency between the structure and content of the two teacher programmes and the in-service teachers' experience of the type of knowledge that the students possess. This article thus contributes to the debate on how different teacher education models contribute to the teacher students' knowledge.
\end{abstract}

Keywords: primary-secondary teacher education, teacher knowledge, pre-service teachers, school practice.

\section{Innledning}

I Norge har lærerutdanningene for grunnskolen vært gjennom hyppige endringer de siste 40 årene. Etter en 100 år lang seminartradisjon med lærerskoler ble lærerutdanningen i 1973 en høyskoleutdanning, og fra 1994 ble også noen 
utdanninger flyttet til universiteter (Rasmussen, 2008). Det ble innført en allmennlærerutdanning i 2003, deretter fulgte grunnskolelærerreformen i 2010 hvor Norge gikk over fra en 4-årig allmennlærerutdanning for lærere på trinn 110 til 4-årige differensierte grunnskolelærerutdanninger rettet mot trinn 1-7 og 510. I 2017 ble en 5-årig masterutdanning innført i alle grunnskolelærerutdanninger. Bakgrunnen for denne omleggingen var blant annet en evaluering av allmennlærerutdanningen som pekte på behov for større spesialisering av lærere mot barne- og ungdomstrinnet. Den anbefalte også å utvide utdanningen til fem år (NOKUT, 2006). Stortingsmelding nr. 16 (20062007) og nr. 31 (2007-2008) hadde fokus på tidlig kartlegging og innsats for elever i grunnskolen. Disse konkluderte med at den tradisjonelle allmennlæreren med mange fag og liten grad av fagspesialisering, ikke dekket behovet for ulike kompetanser og tilpasninger hverken for elever på lavere eller høyere trinn i grunnskolen med skjerpede kompetansekrav i flere fag. I Stortingsmelding nr. 11 (2008-2009) foreslås det derfor en 4-årig lærerutdanning med to differensierte løp for å ivareta behovet for spesialisert kompetanse mot fag, årstrinn og funksjoner. Det var også ønskelig med overlapping i lærerkompetanser på mellomtrinnet (trinn 5-7). I begge utdanningene fikk man et nytt og utvidet pedagogikkfag som også inkluderte elevkunnskap (PEL).

Ved UiT Norges arktiske universitet (UiT) ble det i stedet for å innføre 4-årige grunnskolelærerutdanninger i 2010, startet 5-årige integrerte masterutdanninger for lærere på trinn 1-7 og 5-10. Dette var et nasjonalt pilotprosjekt (Pilot i Nord) med et FoU-basert integrert studiedesign som skulle binde sammen vitenskapsfag og skolens undervisningsfag, profesjonsfagene pedagogikk og fagdidaktikk og ikke minst praksisopplæringen (Engelien, Eriksen, \& Jakhelln, 2015). Utdanningene for 1-7 og 5-10 hadde betydelige forskjeller når det gjaldt omfang av profesjonsfag, så vel som omfang og dybde i skolefagene (UiT, 2017a, 2017b). Ved 1-7 utdanningen fikk pedagogikkfaget spesielt stort omfang, noe som var inspirert av fagets sterke stilling i finsk lærerutdanning (Hansèn, Sjöberg, \& Eilertsen, 2014). Ved 5-10 utdanningen fikk fag og fagdidaktikk større fokus (UiT, 2017a).

I forskningslitteraturen er det ikke konsensus om hva en god lærerutdanning bør inneholde og hvor mye pedagogikk, fag (både bredde og dybde), fagdidaktikk og praksiserfaringer en lærer bør ha for å undervise på ulike trinn i skolen (Cochran-Smith et al., 2015; Levine, 2006; Wilson, Floden, \& Ferrini-Mundy, 2001). I Norden er det gjort lite forskning på hvilken betydning innholdet og strukturen av lærerutdanningene har for utvikling av ulike lærerkompetanser og kunnskapsorienteringer blant studenter og nyutdannede lærerne (Afdal \& Nerland, 2014; Haug, 2008; Haugan, 2011; Rasmussen, 2008). Sammenligningsstudier av nordiske lærerutdanninger viser at de er noe ulike i forhold til omfang av fag, differensiering på skoletrinn, lengde, praksisordninger og institusjonsplasseringer (Haug, 2008; Rasmussen, 2008). Finland har hatt universitetsbasert masterutdanning for lærere siden slutten av 1970-tallet, mens 
Danmark har en seminarbasert 4-årig utdanning. I Sverige varierer lengden på utdanningene fra 3,5 til 5,5 år (mastergrad), og utdanningene er lagt til universiteter og høyskoler.

Lærernes kvalifikasjoner har blitt mye debattert i de siste årene (Brevik \& Fosse, 2016). Det trengs derfor mer kunnskap om hvordan lærerutdanningens innhold og struktur virker inn på studentenes kompetanser og kvalifikasjoner. Dette ønsker vi å se nærmere på i vår studie. Siden 1-7 og 5-10 utdanningene ved UiT Norges arktiske universitet hadde så ulike kompetanseprofiler (UiT, 2017a, 2017b), ga dette oss en god mulighet for en slik studie til å sammenligne disse to utdanningene. I dette arbeidet gjør vi en sammenligning i to dimensjoner. Vi sammenligner først oppbygningen av utdanningene og emneplaner i pedagogikkfaget for 1-7 og 5-10 utdanningene. Deretter sammenligner vi praksislærernes erfaringer med studenter fra de to utdanningene og fokuserer på hvilke kompetanser de viser i praksisopplæringen. Til slutt undersøker vi om det er samsvar mellom praksislærernes erfaringer og oppbygningen av utdanningen og emneplanene. Datagrunnlaget i studien er tekstanalyse av emneplaner for utdanningene og intervjuer med åtte praksislærere på mellomtrinnet som har erfaring med veiledning av studenter både ved 1-7 og 5-10 lærerutdanningene.

I artikkelen presenterer vi først hva tidligere forskning sier om sammenhengen mellom lærerutdanning og kompetanseutvikling hos studenter. Vi gjør deretter rede for kompetansebegrepet og hvordan dette danner rammer for vår studie. Videre blir innsamling av data og resultatene fra analysene av intervjuene og emneplanene presentert. Med dette som grunnlag gir vi en diskusjon rundt samsvar mellom innhold og struktur i lærerutdanninger og kompetanseutvikling hos lærerstudenter. Denne artikkelen er i så måte et bidrag i debatten knyttet til hvordan ulike lærerutdanningsmodeller bidrar til studentenes kompetanser.

\section{Tidligere forskning på lærerutdanningers betydning for kompetanseutvikling}

Lærerutdanningenes oppbygning og programstruktur er nokså ulike rundt omkring i verden og de endres over tid (McKenzie, Santiago, Sliwka \& Hiroyuki, 2005; Wilson et al., 2001). Derfor har det vist seg vanskelig for forskere å gi svar på hvordan forskjellige lærerutdanningsprogram med ulik struktur, fagfordypning og praksisopplæring, virker inn på kompetanseutviklingen til lærerstudentene (Boyd, Grossman, Lankford, Loeb \& Wyckoff, 2005; Cochran-Smith et al., 2015; Wilson et al., 2001). Forskningen gir til dels motstridende resultater, og en har ikke klart å finne klar sammenheng mellom sentrale trekk ved et program og lærerkompetansen som dannes (Haug, 2008). Det etterlyses derfor mer forskning som fokuserer på dette. I vår sammenligningsstudie av to utdanninger med ulik vektlegging av fag, fagdidaktikk og pedagogikk, har vi mulighet til å undersøke 
om praksislærerne erfarer at studentene viser ulike kompetanser i praksisopplæringen.

Den nyeste norske rapporten fra Trends in International Mathematics and Science Study (TIMSS) viser at det er en sterk sammenheng mellom lærernes fagspesialisering, faglige og fagdidaktiske trygghet og deres undervisningskvalitet (Kaarstein, Nilsen \& Blömeke, 2016), noe som igjen virker inn på elevenes prestasjoner i realfagene. Begrepet undervisningskvalitet defineres på ulike måter innenfor pedagogikk og fagdidaktikk, men i TIMSS studien måles undervisningskvalitet ut fra en lærers evne til å være god klasseleder, til å være støttende og til å gi tydelige instruksjoner og kognitivt utfordrende oppgaver i undervisningen (Bergem, Nilsen \& Scherer, 2016). Flere andre studier har også vist at gode kunnskaper i faget læreren underviser i er viktig for å gi god undervisning og et godt læringsutbytte for elevene (Abell, 2007; Driel, Berry, \& Meirink, 2014; Gustafsson \& Nilsen, 2016; Herold \& Waring, 2017; Monk, 1994; Wayne \& Youngs, 2003). I forskningsgjennomgangen av Abell (2007) ser en flere eksempler på at et lavt naturfagnivå hos læreren gir mer lærerstyrt undervisning med mindre grad av elevdeltakelse og fokus på begrepsutvikling. Gjennomgangen viser også at andre lærerkompetanser som kompetanse i pedagogikk og fagdidaktikk, kan kompensere for manglende fagkunnskap. Når det gjelder hvor mye fagkompetanse og spesialisering en lærer trenger fra utdanningen for å undervise på ulike trinn i skolen og hvordan denne kompetansen skal vektlegges i utdanningen, er resultatene fra forskningen ikke entydige (Wilson et al., 2001). Noen studier har konkludert med at økt fagkompetanse over et visst nivå (bachelor eller master), ikke gir høyere læringsutbytte hos elevene (McKenzie et al., 2005; Monk, 1994; Wilson et al., 2001). De fleste av disse studiene er imidlertid gjort på høyere klassetrinn (Gustafsson \& Nilsen, 2016). Det finnes imidlertid studier av lærere på lavere trinn i grunnskolen som viser at mangel på fagkunnskaper gir lærere som blant annet følger lærerboka i større grad, stiller få utforskende spørsmål og i liten grad gjennomfører kognitivt utviklende aktiviteter (Abell, 2007; Driel et al., 2014; Harlen, 1997). Abell (2007) konkluderer i sin litteraturgjennomgang med at det også på lavere trinn er en positiv sammenheng mellom fagkompetanse og kvalitet på undervisning.

Fagdidaktikken henter kunnskap både fra spesifikke fag og pedagogikk og knytter disse kunnskapsområdene sammen (Kind, 2009; Shulman, 1986). Fagdidaktisk kompetanse er en sentral kompetanse for en lærer (Driel et al., 2014; Kind, 2009), og flere studier viser en klar sammenheng mellom hvordan en lærer formidler et fag og elevenes læringsutbytte (Abell, 2007; Gess-Newsome, 2015; Kind, 2009; McKenzie et al., 2005; Schneider \& Plasman, 2011). Forskningsgjennomgangen av Abell (2007) viser at kunnskap om blant annet elevers læring, planverk, undervisningsstrategier og vurdering har betydning for undervisningskvaliteten til en lærer. En studie av Schreiner et al. (Schreiner, Henriksen, Sjaastad, Jensen \& Løken, 2010) viste at lærere som har et sterkt ønske 
om å videreformidle faget til andre, er en viktig inspirasjonskilde for elever ved at de engasjerer dem og gir dem tilknytning til faget. I en forskningsgjennomgang av Kind (2009) argumenteres det med at ved å gjøre fagdidaktikk mer eksplisitt i lærerutdanninger, får en lærere som reflekterer mer rundt sin undervisningspraksis og viser endringskompetanse. I lærerutdanningene i Norden er det vanlig å integrere fagdidaktikken $\mathrm{i}$ fagkursene, og de siste tiårene har fagdidaktikk blitt vektlagt i stadig større grad på bekostning av pedagogikkfaget (Rasmussen, 2008). Dette er en trend en har sett tydelig i Norge og Danmark men ikke i så stor grad i Finland.

Pedagogisk kompetanse er en sentral komponent av lærerens basiskompetanse (Darling-Hammond \& Youngs, 2002; Haug, 2010; Tolo, 2017). Studien av Hattie (2012) peker på at god ledelse av undervisningsarbeid, tilbakemeldinger og gode relasjoner til elever, er faktorer som har god effekt på elevers læring. Det finnes imidlertid lite forskning som direkte ser på sammenhengen mellom hva studenter lærer i pedagogikkfaget, deres undervisningspraksis og elevers læring (Wilson et al., 2001). En årsak kan være at pedagogikk er et så vidt begrep (omfatter blant annet læringspsykologi, sosiologi, klasseledelse) som kan ha ulikt innhold ved forskjellige lærerutdanningsinstitusjoner. Dette gjør det vanskelig å vurdere hvilken betydning faget har i lærerutdanningen og for utvikling av studentenes pedagogiske kompetanse. Wilsons (2001) forskningsgjennomgang viser imidlertid at det er viktig med pedagogikk i lærerutdanningen, men at det er vanskelig å si noe sikkert om hvor mye pedagogikk som trengs på ulike trinn for å gi undervisning av god kvalitet og et høyt læringsutbytte for elevene.

I en internasjonal kvantitativ sammenligningsstudie, ble 11 «kjernekompetanser» for lærere definert (Mohamed, Valcke \& De Wever, 2017). Disse dekket sentrale aspekter ved fag-, fagdidaktikk- og pedagogisk kompetanse. Fire forhold ved lærerutdanningen som utviklet disse kompetansene, ble fremhevet: 1) Eksplisitt undervisning rundt kjernekompetansene 2) Inkludering av kompetansene i læreplanene, 3) Praktisering av kompetansene i skolene og 4) Modellering av kjernekompetansene av lærerutdannerne. Flere studier har og vist at studenter tar med seg teori fra campus og utvikler sin lærerpraksis i lys av denne (Darling-Hammond, 2005, 2008, 2014; Nilssen \& Solheim, 2015; Ulvik, Helleve, \& Smith, 2017). I en nordisk studie ble nyutdannede lærere fra finsk femårig masterutdanning sammenlignet med lærere fra norsk allmennlærerutdanning (Afdal \& Nerland, 2014). Studien konkluderte med at den finske utdanningen som var mer forskningsbasert og koherent enn den norske, påvirket lærernes fagspråk og kunnskapsutvikling i møtet med yrket. Denne studien viser altså at oppbyggingen og innhold i utdanningen hadde betydning for utvikling av kompetanser til fremtidige lærere. Med den eksisterende forskningslitteraturen på dette området som bakteppe, håper vi at vår artikkel kan bidra med mer kunnskap om hvordan ulike utdanningsmodeller virker inn på studentenes kompetanser. 


\section{Teoretisk perspektiv og problemstilling}

Resultater fra studier som fokuserer på kvaliteter hos lærere, viser at lærerens utdanning og kompetanser er de viktigste faktorene for elevers læring (DarlingHammond, 2000; Hattie, 2012; Hill, Rowan \& Ball, 2005; Wayne \& Youngs, 2003). Begrepet kompetanse er sammensatt og har ulike definisjoner og fortolkninger i forskjellige sammenhenger (Tolo, 2017; Weinert, 2001). Et fellestrekk ved definisjonene er at kompetanse handler om personers eller gruppers evne til å møte og håndtere utfordringer i bestemte sammenhenger. I skolesammenheng og innen utdanningsforskning defineres kompetansebegrepet som lærerens kunnskaper, ferdigheter og holdninger til lærerprofesjonen (Lai, Amdam, Martinsen \& Juel, 1997). For lærere er det vanlig å bruke dette brede kompetansebegrepet siden det omfatter både kognitive, sosiale og emosjonelle sider ved yrket. I vår studie har vi valgt å bruke Lai et al. (1997) sin definisjon av kompetansebegrepet. Under utarbeidelsen av intervjueguide har vi ikke delt begrepet inn i kunnskaper og ferdigheter men har fokusert på studentenes kompetanser. Vi har imidlertid inkludert spørsmål om studentenes holdninger til læreryrket.

Forskning på lærernes profesjonelle kompetanseutvikling har gjennom årene brukt ulike modeller for å definere en lærers kompetanseområder (Driel et al., 2014; Gess-Newsome, 2015; Shulman, 1986; Sorge, Kröger, Petersen, \& Neumann, 2017). Felles for alle kompetansemodellene er at både faglig, fagdidaktisk og pedagogisk kompetanse, og kompetanse i konteksten læringen skjer i, er viktig for at elevene skal få et godt læringsutbytte (Ben-Peretz, 2011; Fischer, Borowski \& Tepner, 2011; Gustafsson \& Nilsen, 2016). I vår studie har vi valgt å ta utgangspunkt i de tre førstnevnte kompetansene. Når det gjelder pedagogisk kompetanse, har vi valgt å vektlegge klasseledelse og sosiale relasjoner til elevene. Viktige kunnskapsområder innen fagdidaktikken er kunnskaper om undervisningsstrategier, kunnskaper om elevenes forståelse av faget, kunnskaper om fagets rammeverk og kunnskaper om vurdering i faget (Gess-Newsome, 2015; Grossmann, 1990; Magnusson, Krajcik \& Borko, 1999). I intervjuene ble praksislærerne spurt om deres erfaringer med studentenes fagdidaktiske kompetanse. Vi tolket svarene deres ut fra kunnskapsområdene som er beskrevet ovenfor. Nixon, Hill og Luft (2017) definerer fagkompetanse som kunnskaper om fakta, begreper og praksiser innenfor faget. I intervjuene har vi stilt åpne spørsmål om hvordan praksislærerne erfarte studentenes fagkunnskaper, og om de erfarte at studentene hadde interesse for eller identitet til spesielle fag.

Hovedproblemstillingen i vår studie er som følger:

Er det samsvar mellom hvilke kompetanser som utrykkes i planverk i 1-7 og 5-10 utdanningene og hvilke kompetanser praksislcererne erfarer at studentene fra disse to utdanningene innehar. 
For å svare på dette forskningsspørsmålet stiller vi to delspørsmål:

Hvilke kompetanser utrykkes i emneplanene i pedagogikk og elevkunnskap for 17 og 5-10 utdanningene, og er det ulikheter i oppbygningen av utdanningene?

Hvilke kompetanser erfarer praksislarerne at studenter fra 1-7 utdanningen viser i praksisopplceringen sammenlignet med studenter fra 5-10 utdanningen?

\section{Metode}

I denne kvalitative studien sammenligner vi masterutdanningene for trinn 1-7 og 5-10 som ble opprettet i 2010 ved UiT campus Tromsø. Vi gjør en sammenligning i to dimensjoner. For å besvare første delspørsmål har vi valgt å sammenligne oppbyggingen av utdanningene, og vi har gjennomført en tekstanalyse av emneplanene for faget pedagogikk og elevkunnskap i begge utdanningene. For å få svar på andre delspørsmål har vi intervjuet åtte praksislærere som har veiledet begge studentgruppene, og vi har hatt fokus på deres erfarte kompetanseforskjeller.

Til slutt diskuterer vi om det er samsvar mellom praksislærernes erfaringer og oppbygning av studiet og innhold i emneplanene i pedagogikk og elevkunnskap. Figur 1 viser hva som sammenlignes i studien.

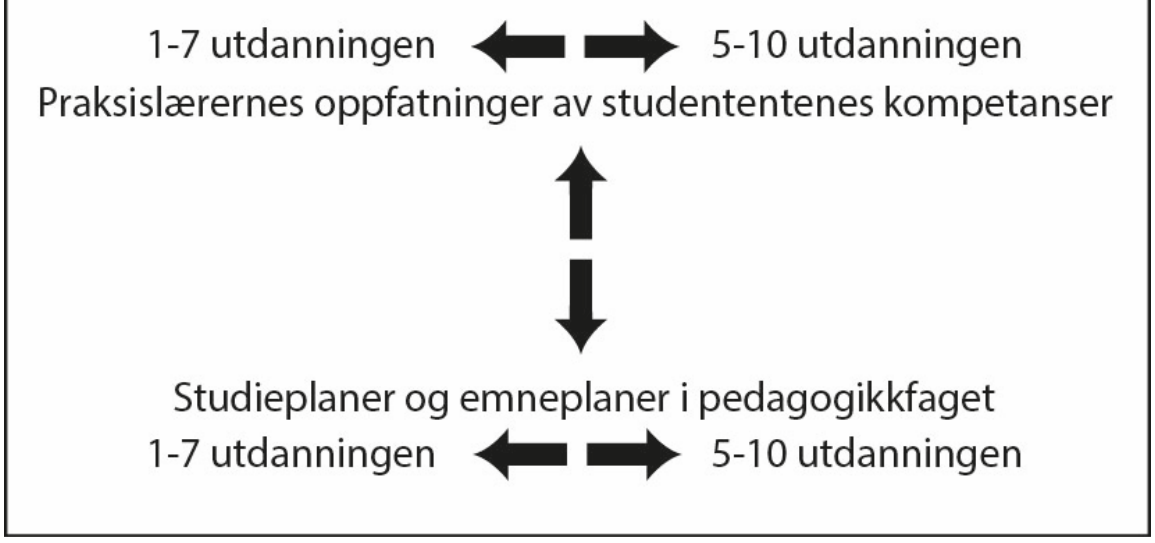

Figur 1 Oversikt over hvilke aspekter ved utdanningene som sammenlignes i studien

I denne studien er studieplaner fra de to utdanningene og emneplaner i pedagogikk og elevkunnskapsfaget valgt ut som data. I tillegg er praksislærere fra trinn 5-7 som har veiledet studenter fra begge utdanningsprogrammene valgt som informanter og har blitt intervjuet for å få svar på våre forskningsspørsmål. Intervju ble valgt siden denne metoden gir innsikt og dybdekunnskap om praksislærernes meninger og vurderinger (Kvale, 1997). Mellomtrinnet ble valgt ut fordi dette var felles praksistrinn for 1-7 og 5-10 utdanningene. Det var et kriterium at lærerne hadde veiledet studenter fra begge utdanningsprogrammene 
de to siste årene. Det viste seg å være relativt få lærere som oppfylte disse kriteriene (ca. 15). Av disse ble 12 forespurt, og 8 sa seg villig til å delta i studien (Tabell 1). Alle informantene arbeidet ved byskoler og begge kjønn var representert. Informantene hadde ulik utdanningsbakgrunn og hadde varierende ansiennitet som lærere (fra 5 til 38 år) og som praksisveiledere (fra 2 til 22 år). Alle unntatt en praksislærer hadde formell kompetanse i veiledningspedagogikk. Fem av lærerne hadde allmennlærerutdanning, mens de resterende hadde fagutdanning på bachelornivå fra et universitet. Flere av allmennlærerne hadde tatt etter- og videreutdanning.

Utdanningsbakgrunn og skolekultur vil kunne prege informantenes holdninger og synspunkter. Det er derfor en styrke for studien at lærere med begge typer utdanning er representert. For at studien skal bli mest mulig transparent, har vi synliggjort lærernes utdanningsbakgrunn (Tabell 1). Praksislærerne vil ha varierende grad av teorigrunnlag knyttet til ulike lærerkompetanser og vil kunne tolke disse noe ulikt. En fordel med å bruke praksislærere som informanter, er at de har vært sammen med studentene over en lengre periode. De har observert studentene planlegge og gjennomføre undervisning og har hatt som oppgave å vurdere studentenes ulike kompetanser. De har dermed vært nødt til å tenke igjennom i hvor stor grad hver enkelt student har oppnådd kompetansemålene for praksisopplæringen. Vi anser derfor praksislærerne som gode informanter i vår studie og deres oppfatninger av studentenes kompetanse er en indikator på studentenes oppnådde kompetanse. Andre studier har også brukt praksislærere som informanter for å få informasjon om studentenes kompetanser (Broemmel, 2006; Moore, 2003).

Vår studie har blitt gjennomført ut fra prinsippene om informert samtykke, anonymisering og informanters muligheter til å avslutte samarbeidet. Studien er godkjent av Norsk samfunnsvitenskapelig datatjeneste og retningslinjene deres er fulgt.

Tabell 1: Oversikt over utdannings- og erfaringsbakgrunn til lærerne og hvilke studentgrupper de har veiledet.

\begin{tabular}{|l|l|l|l|l|}
\hline \multirow{2}{*}{$\begin{array}{l}\text { Infor- } \\
\text { mant }\end{array}$} & $\begin{array}{l}\text { Bakgrunn og type utdanning til } \\
\text { informantene }\end{array}$ & $\begin{array}{l}\text { År som } \\
\text { lærer/ } \\
\text { praksislærer }\end{array}$ & $\begin{array}{l}\text { Studenter } \\
\text { fra } \\
\text { utdanning }\end{array}$ & $\begin{array}{l}\text { Veileder } \\
\text { studenter på } \\
\text { årstrinn: }\end{array}$ \\
\hline 1 & Allmennlærerutdanning & $25 / 17$ & $1-7$ & 3 \\
\hline 2 & $\begin{array}{l}\text { 3-årig allmennlærerutdanning og } \\
\text { påbygging med fag fra universitetet. }\end{array}$ & $38 / 22$ & $5-10$ & 1,2 og 4 \\
\cline { 4 - 5 } & Allmennlærerutdanning & $16 / 6$ & $5-10$ & 2 \\
\hline 3 & & $1-7$ & 3 \\
\hline
\end{tabular}




\begin{tabular}{|c|c|c|c|c|}
\hline \multirow{2}{*}{4} & \multirow{2}{*}{$\begin{array}{l}\text { Fagutdanning fra universitetet og } \\
\text { praktisk pedagogisk utdanning }\end{array}$} & \multirow{2}{*}{$23 / 10$} & $1-7$ & 3 \\
\hline & & & $5-10$ & 1,2 og 3 \\
\hline \multirow[t]{2}{*}{5} & \multirow{2}{*}{$\begin{array}{l}\text { Bachelorutdanning og praktisk } \\
\text { pedagogisk utdanning } \\
\text { universitetet }\end{array}$} & \multirow[t]{2}{*}{$5 / 2$} & $1-7$ & 3 \\
\hline & & & $5-10$ & 1 \\
\hline \multirow[t]{2}{*}{6} & \multirow[t]{2}{*}{ Allmennlærerutdanning } & \multirow[t]{2}{*}{$19 / 6$} & $1-7$ & 1 \\
\hline & & & 5-10 & $2 \operatorname{og} 4$ \\
\hline \multirow[t]{2}{*}{7} & \multirow{2}{*}{$\begin{array}{l}\text { Allmennlærerutdanning og 3-årig } \\
\text { fagutdanning i pedagogikk fra } \\
\text { universitetet }\end{array}$} & \multirow[b]{2}{*}{$30 / 5$} & $1-7$ & 2 \\
\hline & & & $5-10$ & 2 og 4 \\
\hline \multirow[t]{2}{*}{8} & \multirow{2}{*}{$\begin{array}{l}\text { 3-årig fagutdanning fra universitet } \\
\text { og praktisk pedagogisk utdanning }\end{array}$} & \multirow{2}{*}{$12 / 7$} & $1-7$ & 1,2 og 3 \\
\hline & & & $5-10$ & 3 \\
\hline
\end{tabular}

Informantene har veiledet studenter på ulike trinn i utdanningsløpet. Siden studentene har praksis i grupper på tre, har hver informant veiledet minst tre studenter fra hver av de to utdanningene, men flere har veiledet et større antall studenter over flere år. Siden studentene utvikler seg i løpet av studiet, må en være varsom med å sammenligne for eksempel 1. års studenter fra den ene utdanningen med 4. års studenter fra den andre utdanningen. Dette tok vi hensyn til i analysen av intervjuene. I studien har vi ikke kartlagt om det var kompetanseforskjeller mellom studentgruppene ved studiestart. Eventuelle forskjeller i bakgrunnskunnskaper mellom studentgruppene vil kunne påvirke resultatene i studien.

Intervjuguiden ble utarbeidet ut fra et perspektiv om at en lærer trenger kompetanser i pedagogikk, fag og fagdidaktikk. Intervjuguiden var semistrukturert med åpne spørsmål. I intervjuene fikk praksislærerne først åpne spørsmål knyttet til forskjeller mellom studentgruppene. Et eksempel på spørsmål som ble stilt er: «Opplever du noen forskjeller mellom studenter på 1-7 og 5-10 utdanningene?». Etter hvert fikk de mer konkrete spørsmål knyttet til studentenes kompetanser i pedagogikk, fagdidaktikk og fag. Praksislærerne ble også oppfordret til å gi konkrete eksempler fra studentenes praksisopplæring som underbygget deres utsagn. Intervjuene varte i 30-45 minutter og ble gjort på lærernes arbeidsplasser. Vi gjorde lydopptak av intervjuene og transkriberte disse.

I den første delen av studien gjorde vi først en sammenligning av oppbygningen av 1-7 og 5-10 studieprogrammene (UiT, 2017a, 2017b). Deretter gjorde vi en dokumentanalyse av alle emneplanene for faget pedagogikk og elevkunnskap (PEL) i begge utdanningene. I analysen ble alle emneplanene for PEL for studieåret 2016/17 innhentet (UiT, 2017a, 2017b), og læringsmålene for emnene de fire første årene ble sammenstilt for å sammenligne innhold og omfang (se vedlegg 1 ).

Intervjuene ble analysert ut fra en temabasert analytisk tilnærming (Thagaard, 2013) hvor fag, fagdidaktisk og pedagogisk kompetanse ble brukt som 
hovedkategorier. Disse ble valgt ut som kategorier ut fra det teoretiske rammeverket. Vi benyttet også en mer induktiv tilnærming hvor vi så etter temaer i datamaterialet som kunne belyse våre forskerspørsmål. Etter flere gangers gjennomlesninger, gjorde vi meningsfortetninger for hver informant i de ulike kategoriene. På denne måten ble flere og lengre uttalelser komprimert til noen få setninger som gjenga hovedinnholdet innenfor hver kategori for hver informant (Kvale \& Brinkmann, 2015). I tolkningsprosessen ble det lagt vekt på å sammenligne data der lærerne oppfatter forskjeller i kompetanser mellom studentgruppene. Sitater fra forskjellige praksislærere ble valgt ut for å belyse de ulike aspektene, og for å vise variasjon mellom praksislærerne. Praksislærenes oppfatninger av studentenes faglige, fagdidaktiske og pedagogiske kompetanse er nærmere presentert i resultatdelen.

\section{Resultater}

\section{Oppbygging av 1-7 og 5-10 utdanningene ved UiT}

Lærerutdanningene for trinn 1-7 og 5-10 skal utdanne lærere for forskjellige trinn i skolen, men begge utdanningene utdanner lærere for mellomtrinnet (trinn 5-7). For å kunne si noe om på hvilke måter 1-7 og 5-10 utdanningene skiller seg fra hverandre og på hvilke måter de er like, startet vi med å sammenligne studieplaner og oppbygging av studiene (UiT, 2017a, 2017b). Vi laget en enkel tabelloversikt over utdanningene (Tabell 2). En mer detaljert gjennomgang av utdanningene kan leses i Olufsen et al. (2015). Lærerutdanningen ved UiT inneholder et profesjonsfag som omfatter faget «Pedagogikk og elevkunnskap» (PEL) slik det er definert i rammeverket for grunnskolelærerutdanningen (Kunnskapsdepartementet, 2010). Profesjonsfaget har også særskilt ansvar for inkludering og integrering av grunnleggende ferdigheter og FoU i utdanningen. Fra nå av vil vi i denne studien omtale profesjonsfaget som PEL-faget. 1-7 utdanningen er bygd opp av et PEL-fag, fire skolefag hvorav norsk og matematikk er obligatoriske fag. 5-10 utdanningen er satt sammen av tre valgbare skolefag og et PEL-fag inkludert examen pedagogicum (ex. ped.). Begge utdanningene omfatter emnene examen philosophicum (ex. phil.) og forskningsmetode, og studentene får tilnærmet lik praksisopplæring de fire første årene (UiT, 2017a, 2017b). 
Tabell 2. Oppbygging av 1-7 og 5-10 utdanningene ved UiT

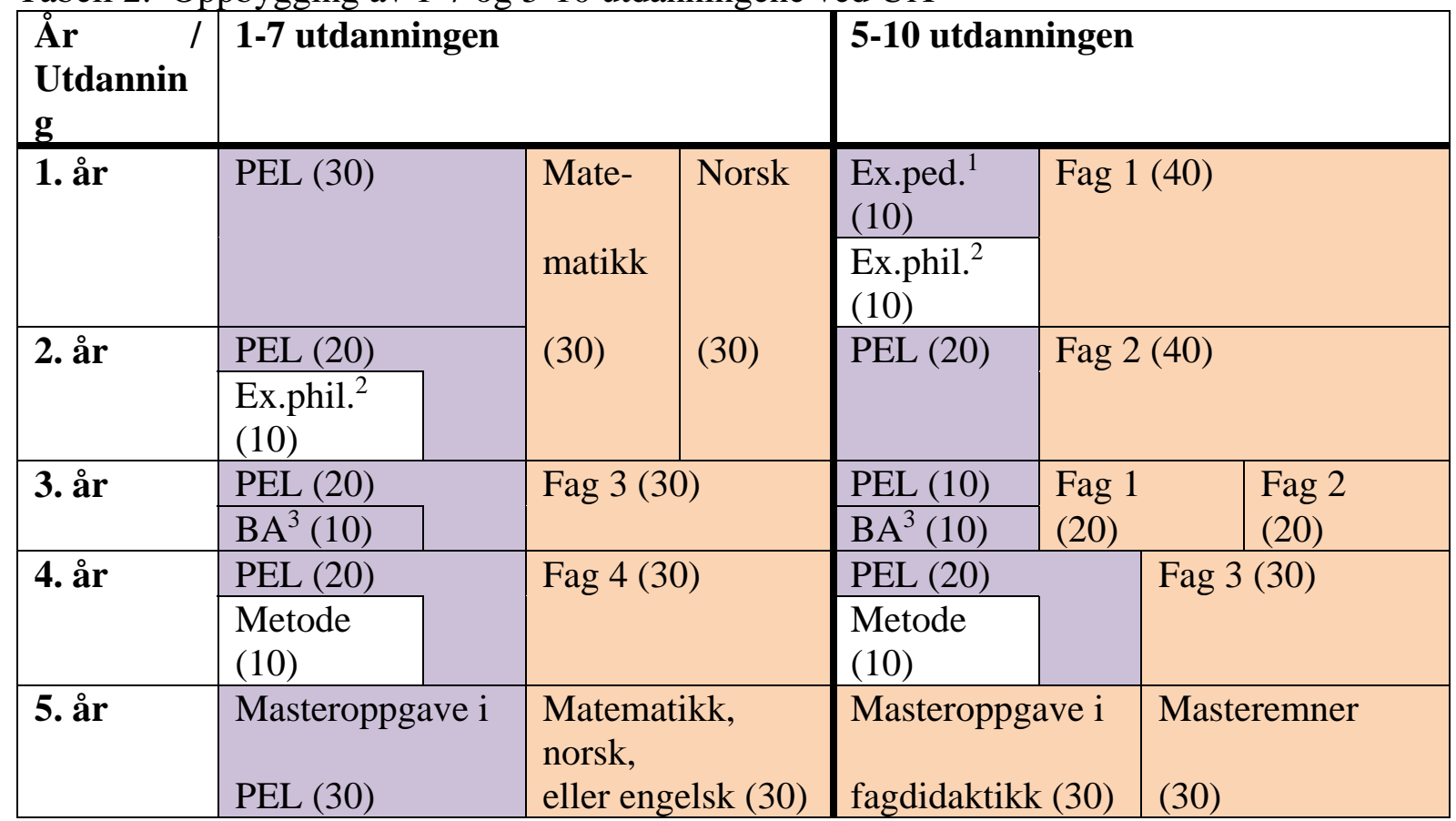

Pedagogikk og elevkunnskap

Fag/fagdidaktik

${ }^{1}$ Examen pedagogicum, `Examen philosophicum, ${ }^{5}$ Bacheloroppgave, Parentes angir antall studiepoeng

Hovedforskjellen mellom utdanningene er at PEL-faget som er masterfag på 1-7 utdanningen, har 60 studiepoeng (stp, 1stp=1ECTs) større omfang på denne utdanningen sammenlignet med 5-10 utdanningen (Tabell 2). Til gjengjeld har 510 utdanningen større grad av fordypning og fagspesialisering, spesielt i masterfaget hvor studentene oppnår 120 stp. En annen forskjell er at 1-7 utdanningen har matematikk og norsk som obligatoriske fag de to første årene, mens studentene på 5-10 utdanningen velger Fag 1 (masterfaget) og Fag 2 disse årene. Tredje studieår velger studentene på 1-7 utdanningen et nytt Fag 3, mens 5-10 studentene bygger på Fag 1 og Fag 2 og oppnår 60 stp i begge fag. Fjerde år velger studentene på 1-7 utdanningen et siste fag (Fag 4), mens studentene på 510 utdanningen velger Fag 3. Siste semester skriver studentene masteroppgaver i PEL og i fagdidaktikk på hhv. 1-7 og 5-10 utdanningen. Vår sammenligning viser at det er store forskjeller i oppbygging av utdanningene. Dette gjelder spesielt i starten av studiene.

\section{Analyse av emneplaner i PEL-faget}

For å undersøke om det er forskjeller i innholdet i PEL-faget i 1-7 og 5-10 utdanningene, har vi laget en sammenstilling av emneplanene de fire første årene, se Vedlegg 1. Vi har også gjennomført en tekstanalyse av emneplanmålene. Tekstanalysen av emneplanmålene viser at første år er hovedfokuset lærerrollen og læreplanverket. Da inneholder begge emneplanene mange like temaer og mange av emneplanmålene er like. Emneplanen for 1-7 utdanningen har 
imidlertid temaer om tilpasset opplæring, læringsmiljø og grunnleggende generell didaktikk, noe som emneplanen for 5-10 utdanningen ikke har. Denne utdanningen har til gjengjeld noe mer fokus mot fagdidaktikk. Et eksempel på et slikt emneplanmål er at studentene skal lære om fagdidaktisk tenkning og arbeid i lys av læreplaner. Omfanget av PEL-faget første året er tre ganger så stort på 17 utdanningen målt i antall studiepoeng. Siden det er liten forskjell mellom antall kompetansemål i emneplanene, kan en gå mer i dybden på temaene og har betydelig mer tid til refleksjon i 1-7 utdanningen.

Hovedtemaene andre år for PEL er elevkunnskap og tilpasset opplæring i begge utdanningene, og emnene har samme omfang. Utdanningene har felles temaer som didaktisk refleksjon knyttet til relasjonskompetanse, klasseledelse og vurdering av læringsprosesser, men i emneplanen for 5-10 utdanningen er det spesifisert at en skal jobbe med formativ vurdering og grunnleggende ferdigheter i fagene. Av analysen ser en altså at emneplanen for 5-10 utdanningen er mer fagdidaktisk rettet og har mer fokus mot utvikling av fagdidaktisk kompetanse.

Hovedtemaet for PEL tredje år er «Den profesjonelle lærer i en lærende organisasjon». I tillegg inngår en forsknings- og utviklingsoppgave (FoUoppgave) i emnene for begge utdanningene. Læringsmålene som omhandler samarbeid i skolen og mot hjemmet og yrkesetikk, er identiske i begge utdanningene. På 1-7 utdanningen har imidlertid emnet dobbelt så stort omfang. Det er derfor grunn til å tro at disse temaene blir behandlet grundigere og gir tid for mer refleksjon på 1-7 utdanningen.

Hovedtemaet fjerde år for PEL er eleven, skole og samfunn. 1-7 utdanningen har ett emne på 20 stp, mens 5-10 utdanningen ha to emner på 10 stp hver. Det ene emnet på 5-10 utdanningen er om ungdom, kultur og identitet og er rettet mot arbeid på ungdomstrinnet. Den andre PEL-emnet på 5-10 utdanningen har tilnærmet identiske emneplanmål med emnet på 1-7 utdanningen, men har bare halve omfanget i studiepoeng. Felles temaer er refleksjon rundt lærerens praksis og skolens kontaktflate mot samfunnet. En vesentlig forskjell er at det er spesifisert refleksjon over fagdidaktisk praksis for 5-10 utdanningen og oppdragelsespraksis for 1-7 utdanningen.

Vår sammenligning viser at emneplanmålene i 1-7 utdanningen har noe mer fokus på generell pedagogikk/didaktikk slik som tilpasset opplæring, læringsmiljø og oppdragelsespraksis. 5-10 utdanningen derimot, har noe mer fokus mot fagdidaktikk, for eksempel grunnleggende ferdigheter og formativ vurdering i skolefagene. En vesentlig forskjell er at 1-7 utdanningen har 90 stp PEL-fag de fire første årene mens 5-10 utdanningen kun har 60 stp. Antall emneplanmål for faget er relativt likt i de to utdanningene, dette betyr at 1-7 utdanningen har færre emneplanmål per studiepoeng enn 5-10 utdanningen. Studenter ved 1-7 utdanningen har altså langt bedre tid til å fordype i PEL-faget sammenlignet med studenter ved 5-10 utdanningen. 


\section{Praksislærernes oppfatninger av studentenes faglig kompetanse}

I denne studien ønsket vi å undersøke om praksislærerne erfarer forskjeller i kompetanse mellom studentgruppene fra de to ulike utdanningene. Praksislærerne fremhever at kompetanse i skolefagene er viktig på mellomtrinnet og hevder at en gjennom faglig trygghet fremstår som en god og betydningsfull klasseleder. Det er tydelig at praksislærerne anerkjenner viktigheten av faglig kompetanse på mellomtrinnet.

I intervjuene ble praksislærerne bedt om å vurdere om det er forskjeller i fagkompetanse mellom studenter på 1-7 og 5-10 utdanningene. Praksislærerne mener at studentene på 5-10 utdanningen har større fagfokus og er sterkere og tryggere faglig enn studentene på 1-7 utdanningen. Dette gjelder spesielt i fagene de har fra utdanningen. De viser også større interesse for og er mer motivert for å undervise i disse fagene. Et sitat fra en praksislærer som har opplevd forskjeller er:

Jeg opplever at 5-10 studentene har en høyere faglig kompetanse, hvert fall i fagene som de har hatt. De er mye mer bevisst på faget sitt. De er veldig stolt av det faget de underviser i, og føler at de er eksperter på det området kontra 1-7 studentene som kanskje føler at de ikke eier et fag, men har mange fag som de skal dekke (informant 4).

Selv om praksislærerne opplever studentene fra 5-10 utdanningen som faglig sterkere, kommer det også frem at dette er personavhengig og avhengig av hvor studentene er i studieforløpet. To informanter (informant 1 og 3) mener at det ikke er forskjeller i faglig kompetanse mellom studentgruppene. De har imidlertid veiledet 5-10 studenter tidlig $i$ utdanningen og 1-7 studenter sent i utdanningsløpet, og synes av den grunn det er vanskelig å si noe om faglige forskjeller mellom studentgruppene. Ut fra lærernes erfaringer ser vi en tendens mot at studentene fra 5-10 utdanningen har høyere fagkompetanse enn de fra 1-7 utdanningen.

Det kan se ut som det å arbeide med et fag i dybden har betydning for hvor godt studentene forbereder seg i andre fag som de har mindre kompetanse i. To praksislærerne nevner at studentene på 5-10 utdanningen har skjønt at det kreves mer forberedelse når de har manglende faglig bakgrunn. En av dem sier:

Om ikke studentene på 5-10 utdanningen er faglig sterkere, så har de mer faglig trygghet og bruker kanskje mer tid siden de ikke har så mange fag som 1-7 studentene har. Så det krever mye mer forberedelse siden de faktisk må sette seg inn i det. De bruker mer tid på å heve nivået sitt i forkant av undervisning og i nye temaer som kanskje er ukjent for dem (Informant 8).

Praksislærerne erfarte at det var holdningsforskjeller mellom studentgruppene til det å undervise i fag de ikke hadde fått undervisning i fra campus. Studentene på 1-7 utdanningen var mer villige til dette. Noen praksislærere sier at studentene på 
1-7 programmet som har fagkompetanse i flere fag i større grad ser på seg selv som allmennlærere med kontaktlæreransvar.

Praksislærerne erfarer at studenter på 5-10 utdanningen oppfatter seg mer som faglærere i sine fag. Tre lærere nevner at norsk er viktig for å undervise i flere fag og er kritiske til at studenter på 5-10 utdanningen ikke nødvendigvis velger norsk som ett av fagene. De mener at dette gjør studentene mindre egnet som lærere på barnetrinnet (trinn 1-7) siden norskfaget er viktig når grunnleggende ferdigheter skal integreres i alle fag. En sier:

Du skal jo kommunisere skriftlig og muntlig med elever i alle fag og med foreldrene, og da må norsken ligge der. Det er jo et verktøysfag.

Noen praksislærerne fremhever at siden de fleste lærere som ansettes på mellomtrinnet får kontaktlæreransvar, bør de ha matematikk eller norsk som fag. Av den grunn mener praksislærerne at lærere fra 1-7 utdanningen er mest tilpasset og anvendelige på mellomtrinnet. Et annet viktig poeng som nevnes er at lærere fra 1-7 utdanningen kan brukes på alle trinn i barneskolen. Samtidig sier tre praksislærerne at lærere med fagdidaktisk masterutdanning kan være ressurslærere i sine fag og opptre mer som faglærere på mellomtrinnet. En sier:

Jeg er ikke helt overbevisst om at allmennlæreren som underviser klassen sin i alle fag, er den beste løsningen. Klassen min ville nok fătt bedre undervisning i noen fag hvis de hadde hatt en lærer som brant for faget og kunne det skikkelig godt (Informant 5).

Analysen av intervjuene viser en tendens mot at praksislærerne opplever forskjeller i faglig kompetanse mellom studentene på 1-7 og 5-10 utdanningene, og at studentgruppene har ulike holdninger til det å undervise fag de ikke har kompetanse i fra campus.

\section{Praksislærernes oppfatninger av studentenes fagdidaktiske kompetanse}

Når det gjelder forskjeller i fagdidaktisk kompetanse mellom studentene fra 1-7 og 5-10 utdanningene, har de fleste erfart at begge studentgrupper har hatt et reflektert forhold til læreplanen i faget, læringsmål for undervisningsøktene og hvordan de kommuniserer faget til elevene. Dette tyder på at begge studentgruppene vektlegger fagdidaktikk når de planlegger og gjennomfører undervisning. Fire av praksislærerne mener imidlertid at studentene fra 5-10 utdanningen har hatt mer fokus på fagdidaktikk og har hatt et bredere spekter av læringsstrategier, tilnærmingsmåter og undervisningsmetoder i faget. Det trekkes også frem at studentene fra 5-10 utdanningen har vært mer selvstendige, uredde og innovative i undervisningsplanleggingen. Dessuten har de krevd mindre veiledning. En lærer sier at:

Studentene ved 5-10 utdanningen har vært mer innovativ i forhold til nytenkning og planlegging av undervisning. Altså det å komme på gode undervisningsopplegg og at 
de på en måte virker som de er mer forberedt. Studentene fra 1-7 har vært mer usikre og litt mer sånn forsiktige, men studentene fra 5-10 er liksom litt mer frampå. De har hatt gode forslag og veiledningsøktene har også vært til dels bedre og med mer faglig innhold (Informant 4).

Praksislærerne erfarer at studentene fra 5-10 utdanningen viser god fagdidaktisk kompetanse, allerede fra tidlig i utdanningen. To praksislærere erfarer derimot at studentene på 5-10 utdanningen har vært så opptatt av det rent faglige, at dette har gått ut over det metodiske og didaktiske. Disse mener at studentene på 5-10 utdanningen strever med å tilpasse det faglige nivået til mellomtrinnet og har for høye forventinger til hva elevene skal kunne fra småskoletrinnet. De opplever at studentene fra 1-7 utdanningen har vært flinkere å tilpasse undervisningen til elevene på mellomtrinnet. Av den grunn etterlyser lærerne at lærerutdanningen har mer fokus på læreplanverket for hele barneskolen for begge studentgruppene. En av disse sier at:

Jeg har opplevd at de (studenter på 5-10 utdanningen) strever med å tilrettelegge undervisningen sin og de har for store forventinger til hva elevene kan. Om du skal jobbe i femte og ikke har noen ide om hva som foregår fra trinn 1-4, så hvordan vet du hvor du skal begynne i femte? (Informant 1)

En praksislærer opplever at studentene på 1-7 utdanningen har hatt en mer «leken tilnærming» til ungene og har hatt større grad av variasjon i sin undervisning. Læreren hevder at disse studentene ikke har vært så redde for å mislykkes som studentene på 5-10 utdanningen, og har av den grunn turt å prøve ut ulike undervisningsopplegg. Analysen av intervjuene viser likevel en trend mot at praksislærerne erfarer at studentene på 5-10 utdanningen har vist et større repertoar av fagdidaktiske tilnærminger i sin undervisning, og har vist mer kunnskap innenfor dette kompetanseområdet.

\section{Praksislcerernes oppfatninger av studentenes pedagogiske kompetanse}

Som tidligere beskrevet, fremhever praksislærerne faglig kompetanse som viktig for lærere på mellomtrinnet. De anser imidlertid pedagogisk kompetanse som like viktig for lærere på dette trinnet. Det som trekkes frem som spesielt viktig er kontaktlærerrollen, klasseledelse og det å kunne bygge gode relasjoner til både elever og foreldre.

Praksislærerne erfarer at begge studentgruppene har fokus på pedagogikk i praksisopplæringen, og lærerne veileder spesielt i starten mye i klasseledelse og klassemiljø. De pedagogiske forskjellene praksislærerne opplever er mer personavhengig og avhengig av hvor langt studentene har kommet i utdanningsløpet, enn selve utdanningen. Tre praksislærere mener derimot at studentene fra 1-7 utdanningen har et mer reflektert forhold til elever med spesielle behov, klasseledelse og kontaktlærerrollen. En av disse nevner også at studentene fra 1-7 utdanningen har vist større kompetanse innenfor 
relasjonsbygging siden de har arbeidet med yngre barn tidligere gjennom praksis på småskoletrinnet. Studentene på 1-7 og 5-10 utdanningene har normalt praksis på hhv. småskoletrinnet (trinn 1-4) og mellomtrinnet (trinn 5-7) de to første årene av studiet. Tredje studieår er praksisen normalt på neste trinn. Utsagnene ovenfor tyder på at det er positivt at studentene fra 1-7 utdanningen har praksiserfaring fra småskoletrinnet. Fordelen er at studentene kjenner elevenes kunnskapsnivå og kognitive nivå fra småskolen. Studentene fra 5-10 utdanningen vil få samme positive effekt når de har praksis på ungdomstrinnet ved at de har kunnskap om elevene på mellomtrinnet.

Praksislærerne erfarer at begge studentgruppene etter hvert i studieforløpet blir mer interessert i klasseledelse, gode sosiale relasjoner med elevene og ikke minst samarbeidet mellom skole og hjem. En av disse sier at:

Fokuset endrer seg jo eldre man blir og da er man mer nysgjerrig på klasseledelse. Det er klasseledelse jeg veileder studentene i uansett hvilket fag de har. Om det kommer opp en situasjon i klasserommet, må vi også snakke om skole-hjem samarbeid (Informant $6)$.

Det kommer imidlertid også frem i intervjuene at 5-10 studentene oppleves mer som faglærere og at flere sikter mot jobb på ungdomstrinnet. De oppleves derfor ikke som like reflekterte rundt kontaktlærerrollen. Det hevdes også at relasjonsbygging er for lite vektlagt på 5-10 utdanningen, og at 1-7 studentene har et reflektert forhold til dette og hvordan en blir en god kontaktlærer. Det erfares også at studentene på 1-7 utdanningen har noe mer oversikt over pedagogiske begreper og teori. En praksislærer hevder at:

Studentene fra 1-7 utdanningen hadde litt mer forståelse for det grunnleggende og ser mer elever med spesielle behov og det her med klassemiljø, klassestruktur og pedagogikk. De i fjor følte jeg hadde litt mer oversikt. De hadde fått lært mer om klasseledelse (Informant 7).

En annen praksislærer har derimot erfart at flere av studentene i 5-10 gruppene har stilt høyere krav til han som veileder, og mener at begge studentgruppene har vært opptatt av sosiale relasjoner og sett viktigheten av dette. Det hevdes også at 5-10 studentene har skjønt at de også må jobbe grundig med pedagogikkfaget siden de har langt mindre pedagogikk i studiet sitt. Et sitat som viser dette er:

En av grunnene til at jeg ofte ikke merker så stor forskjell på studentgruppene er at studentene fra 5-10 kanskje legger et sånt alvor i fagligheten. De tar med seg dette alvoret og skjønner at hva de må gjøre når det gjelder klasseledelse og pedagogikk. Det handler om jo faglighet dette også (Informant 8).

Analysen av intervjuene viser at praksislærerne har ulike erfaringer med studentgruppene i forhold til pedagogisk kompetanse. Vi ser en tendens mot at pedagogisk kompetanse er personavhengig og mer avhengig av hvor studentene 
er i utdanningsløpet enn hvilken utdanning de tilhører. Tre praksislærere erfarer imidlertid at studentene fra 1-7 utdanningen virker mer reflekterte og er mer opptatt av sentrale pedagogiske temaer.

\section{Diskusjon og konklusjon}

I 2010 startet UiT opp to relativt ulike masterutdanninger for lærere, en for trinn 1-7 og en for trinn 5-10. Selv om utdanningene er ulike, rekrutter de lærere til mellomtrinnet. I diskusjonen vil vi først sammenligne oppbygningen av disse utdanningene og emneplanene i pedagogikkfaget. Deretter vil vi diskutere praksislærernes erfaringer med å veilede studenter fra de to utdanninger. Til slutt vil vi gjøre en sammenligning for å se om det er samsvar mellom utdanningenes planverk og praksislærernes erfaringer med studentenes kompetanse.

Sammenligningen av oppbygningen av 1-7 og 5-10 studiene viser at de har svært lik praksisopplæring, og mange av universitetslærerne underviser også på begge studiene. Studentene på 5-10 utdanningen har frihet til selv å velge fag, mens 1-7 studentene har to obligatoriske fag. 1-7 utdanningen gir studentene kompetanse i fire skolefag, ett fag mer enn studentene ved 5-10 utdanningen. Analysen av oppbygningen av utdanningene viser at studentene på 1-7 utdanningen får betydelig mer pedagogikk og elevkunnskap enn studentene på 510 utdanningen. Siden PEL-faget i de to utdanningene inneholder omtrent like mange emneplanmål i de fire første årene, er det rimelig å anta at studentene på 1-7 utdanningen har mer tid og mulighet til å gå i dybden på pedagogiske problemstillinger. Dette er et godt utgangspunkt for å gi disse studentene dybdekunnskaper i pedagogikk og elevkunnskap. Studentene på 5-10 studiet derimot, får en mye sterkere fagspesialisering, særlig i masterfaget. Det er store strukturelle forskjeller, spesielt i første år av utdanningene. 1-7 utdanningen vektlegger pedagogikk og obligatoriske fag dette året, mens 5-10 utdanningen vektlegger masterfaget. Analysen av emneplanene for PEL-faget viser at emneplanmålene for de to utdanningene er relativt like, men det er noen forskjeller. 5-10 utdanningen har noe mer fokus mot fagdidaktikk, mens 1-7 utdanningen vektlegger tilpasset opplæring og relasjonell kompetanse noe mer.

I andre del av studien ble praksislærerne intervjuet om deres erfaringer med å veilede studenter på 1-7 og 5-10 utdanningene. Vi har brukt praksislærernes erfaringer som en indikator på studentenes oppnådde kompetanse. Vi valgte ut lærere som hadde erfaring med veiledning av begge studentgruppene, og i intervjuet fokuserte vi spesielt på forskjeller i kompetanser mellom studentgruppene. Praksislærerne fremhevet at både kompetanse i fagene de underviser og pedagogisk kompetanse er viktig for en lærer på mellomtrinnet. De erfarte at studentene ved 5-10 utdanningen hadde mer kompetanse og interesse for fag og fagdidaktikk enn studentene ved 1-7 utdanningen. Dette gjaldt i hovedsak i fagene de hadde valgt som studiefag ved campus. Studentene ved 5- 
10 utdanningen viste et bredere spekter av læringsstrategier og undervisningsmetoder i sine fag. Praksislærerne erfarte også at studentene fra denne utdanningen var mer selvstendige, faglig trygge og innovative i undervisningsplanleggingen. Dessuten krevde de mindre veiledning. Hovedforskjellen i fagdidaktisk kompetanse mellom studentgruppene var innenfor kunnskap om undervisningsstrategier, som er et sentralt område innenfor fagdidaktisk kompetanse (Gess-Newsome, 2015).

Når det gjaldt pedagogisk kompetanse, erfarte noen av praksislærerne at studentene fra 1-7 utdanningen var mer opptatt av pedagogiske temaer som sosiale relasjoner, klasseledelse og tilpasset opplæring enn studentene ved 5-10 utdanningen. Praksislærerne erfarte også at det var forskjeller i holdninger til det å undervise i mange fag mellom studentgruppene. Studentene ved 5-10 utdanningen var mer motvillige til å undervise $\mathrm{i}$ fag de ikke hadde fått undervisning i fra campus, og så på seg selv mer som faglærere. Studentene ved 1-7 utdanningen derimot, var mer villige til å undervise i flere fag, og praksislærerne opplevde at de så på seg selv mer som allmennlærere med kontaktlæreransvar. Ut fra praksislærernes erfaringer kan en si at det var forskjeller i kompetanser mellom studentgruppene, både innenfor fag, fagdidaktikk og pedagogikk. I vår studie har vi valgt å undersøke forskjeller i studentenes kompetanser på et mer overordnet nivå. Studien har derfor ikke så høyt detaljnivå innenfor hvert kompetanseområde.

Til slutt i diskusjonen ønsker vi å drøfte om det er samsvar mellom oppbygningen av utdanningene og kompetansemålene i emneplanene med hvilke kompetanser praksislærerne erfarte at studentene innehar. Ut fra studieplaner og emneplaner i pedagogikk og elevkunnskap ser en at fag og fagdidaktikk vektlegges sterkere i 5-10 utdanningen sammenlignet med 1-7 utdanningen. Praksislærerne erfarte at studentene på 5-10 utdanningen hadde høyere kompetanse i sine valgte fag. De var også mer dedikerte til og hadde større interesse for å undervise i fagene de hadde kompetanse i. Vi tolker dette dithen at det var samsvar mellom planverk og hvilke kompetanser praksislærerne erfarer at studentene har innenfor fag og fagdidaktikk. At 5-10 utdanningen bidrar til faglig kompetente lærere støttes av en annen studie vi har gjort i naturfag på 5-10 utdanningen (Olufsen, Karlsen \& Ødegaard, 2017) og av en ekstern evaluering av samme utdanning (UiT, 2016). Studien til Schreiner et al. (2011) viser at lærere som føler eierskap og ønsker å videreformidle faget til andre, er viktige både for elevers læring og som inspirasjonskilde ved at de engasjerer elevene. Siden flere studier viser at det er en sammenheng mellom lærernes fagspesialisering, faglige og fagdidaktiske trygghet og deres undervisningskvalitet (Blömeke, Suhl, Kaiser \& Döhrmann, 2012; Hill et al., 2005; Kaarstein et al., 2016), er det positivt at studentene fra 5-10 utdanningen ser ut til å inneha disse kompetansene.

Når det gjelder pedagogisk kompetanse er det også et visst samsvar mellom planverk og praksislærernes erfaringer. Studentene ved 1-7 utdanningen får langt mer undervisning i pedagogikk og elevkunnskap enn studentene ved 5-10 
utdanningen, og noen praksislærerne erfarte at studentene på 1-7 utdanningen var mer fokusert på pedagogisk tematikk. At det er samsvar mellom planverk og praksislærernes erfaringer, støttes også av at det er samsvar mellom sentrale temaer i emneplanen i PEL-faget tidlig i studiet og hva praksislærerne erfarer at studentene på 1-7 utdanningen vektlegger i praksisopplæringen. Det at studentene fokuserer på samme tematikk både i praksisopplæringen og i teoriundervisningen, kan bidra til at læringen i pedagogikk forsterkes. Studentene kan få prøvd ut teorien de har arbeidet med på campus i praksisopplæringen. Flere studier har vist at lærerstudenter ved utdanninger med god sammenheng mellom praksisopplæringen og emner på campus, bedre klarer å anvende teoretiske begreper når de har praksis i skolene (Allsopp, De Marie, Alvarez-MvHatton \& Doone, 2006; Hammerness et al., 2005; Mohamed et al., 2017). Også nordiske studier har vist at en nær sammenheng mellom teori fra campus og praksiserfaringer styrker lærerutdanningene (Haug, 2008; Hopmann, 2006; Nilssen \& Solheim 2015; Rasmussen, 2008).

Vår studie tyder på at det er samsvar mellom studentenes kompetanse og planverket i utdanningen. Ut fra det begrensede antall informanter i denne studien kan vi ikke fastslå at det er en sammenheng. Det er imidlertid nærliggende å tro at det er en sammenheng, men dette må undersøkes nærmere. En mulig forklaring på forskjellene praksislærerne erfarte mellom studentene fra de to utdanningene kan være at det er betydelige forskjeller i oppbygningen av utdanningene første studieår. Studentene på 5-10 utdanningen får allerede fra første år høy grad av fordypning i masterfaget, mens 1-7 studentene tar to obligatoriske fag de første to årene og har mer fordypning i PEL-faget. Dette kan bidra til at 5-10 studentene i større grad tidlig får faglig og fagdidaktisk kompetanse i masterfaget. Dette kan også forsterkes ved at de får praksisopplæring i dette faget i de fleste praksisperiodene gjennom studiet (Karlsen, Olufsen, Haugland \& Thorvaldsen, 2017; Olufsen, Karlsen, Sæleset, \& Thorvaldsen, 2019). Muligheter til å praktisere undervisning, er en dimensjon ved lærerutdanninger som har vist seg å styrke utviklingen av lærerkompetanser (Cochran-Smith \& Villegas, 2015; Hammerness, 2013; Korthagen, 2010).

Det at praksislærerne erfarer at studentene ved 1-7 utdanningen er mer villige til å undervise flere fag enn studentene ved 5-10 utdanningen, tyder på at studentene påvirkes av innhold og struktur i utdanningene og dermed utvikler ulike holdninger til læreryrket. En mulig forklaring på dette er at det store PELfaget, større fagbredde og obligatoriske fag ved 1-7 utdanningen, bidrar til at disse studentene ikke i samme grad som 5-10 studentene knyttes til ett eller to skolefag. Det er positivt for skolen at det utdannes lærere som er villige til å undervise i mange fag og dermed har mulighet til å knytte nære sosiale relasjoner med elevene. På en annen side kan lærere som underviser i mange fag, ha manglende faglig og fagdidaktisk fordypning i noen av fagene de underviser i (Abell, 2007; Driel et al., 2014). Dette kan gå ut over elevenes læringsutbytte siden lærerens 
kompetanse i fag og fagdidaktikk er viktig for læring (Herold \& Waring, 2017; Kaarstein et al., 2016; Wayne \& Youngs, 2003).

Våre resultater antyder at programstruktur og innhold ved lærerutdanningene har betydning for hvilke kompetanser lærerstudenter utvikler. Dette samsvarer med studien av Afdal \& Nerland (2014) hvor nyutdannede lærere fra finsk femårig masterutdanning ble sammenlignet med lærere fra norsk allmennlærerutdanning. Studien konkluderer med at den finske utdanningen, som var mer forskningsbasert og koherent enn den norske, påvirket lærernes kunnskapsorientering i møtet med yrket. Også internasjonale studier har vist at innhold og oppbygging av lærerutdanningen har betydning for hvilke kompetanser og holdninger studentene utvikler (Cochran-Smith \& Villegas, 2015; Cochran-Smith et al., 2015; Darling-Hammond, 2005; Hammerness et al., 2005; Mohamed et al., 2017). Utdanningene i vår studie ser ut til å gi lærerstudenter med noe ulike kompetanseprofiler. 1-7 utdanningen gir studenter som ser på seg selv som allmennlærere med kontaktlæreransvar, mens 5-10 utdanningen gir mer faglærere. Disse ulike «lærertypene» skal undervise og samarbeide på mellomtrinnet. Det blir interessant å se om skolen kan nyttiggjøre seg både lærere fra 5-10 utdanningen med en kompetanseprofil rettet mot fag og fagdidaktikk og lærere fra 1-7 utdanningen med mer fokus på pedagogikk og en bredere fagprofil. Det ville være interessant å forske mer på om lærere fra 1-7 og 5-10 utdanningene får ulike funksjoner og oppgaver på mellomtrinnet i norsk skole fremover.

Høsten 2017 ble grunnskolelærerutdanningene i Norge for trinn 1-7 og 5-10 masterutdanninger. Ifølge de nasjonale rammeverkene (Kunnskapsdepartementet, 2016a, 2016b) skal studentene ha 60 stp pedagogikk inkludert religion, livssyn og etikk. Masteroppgaven på 1-7 utdanningen kan være rettet mot fagdidaktikk, begynneropplæring i fag, profesjonsrettet pedagogikk eller spesialpedagogikk. De to sistnevnte skal også være vinklet mot skolefag. En ser altså en utvikling hvor fagligheten har blitt styrket ved 1-7 utdanningen i forhold til de tidligere utdanningene for trinn 1-7. Den har altså blitt mer lik 5-10 utdanningen. Dette er i tråd med St. meld. nr. 11 (11, 2008-2009) hvor det fremheves at solid faglig kompetanse hos læreren gir faglig trygghet, og er nødvendig for å kunne differensiere opplæringen av barn og ungdom på en god måte.

\section{Om forfatterne}

Solveig Karlsen er førsteamanuensis ved UiT Norges arktiske universitet. Hennes forskningsinteresser omfatter blant annet kvalitet i lærerutdanningen og forholdet mellom utforskende undervisning og læring i naturfag.

Institusjonstilknytning: Institutt for lærerutdanning og pedagogikk, UiT Norges arktiske universitet, Postboks 6050 Langnes, 9037 Tromsø.

E-post: solveig.karlsen@uit.no 
Magne Olufsen er førsteamanuensis ved UiT Norges arktiske universitet. Hans forskningsinteresser omfatter blant annet kvalitet i lærerutdanningen, studentaktive arbeidsmåter og sammenheng mellom undervisning og læring i naturfag.

Institusjonstilknytning: Institutt for lærerutdanning og pedagogikk, UiT Norges arktiske universitet, Postboks 6050 Langnes, 9037 Tromsø.

E-post: magne.olufsen@uit.no

\section{Referanser}

Abell, S. K. (2007). Research on science teacher knowledge. I S. Abell \& N. G. Lederman (Red.), Research on Science Teacher Education (s. 1105-1149). New York: Routledge.

Afdal, H. W. \& Nerland, M. (2014). Does Teacher Education Matter? An Analysis of Relations to Knowledge among Norwegian and Finnish Novice Teachers. Scandinavian Journal of Educational Research, 58(3), 281-299. doi: https://doi.org/10.1080/00313831.2012.726274

Allsopp, D. H., De Marie, D., Alvarez-MvHatton, P. \& Doone, E. (2006). Bridging the Gap between Theory and Practice: Connecting Courses with Field Experiences. Teacher Education Quarterly, 33(1), 19-35.

Ben-Peretz, M. (2011). Teacher Knowledge: What Is It? How Do We Uncover It? What Are Its Implications for Schooling? Teaching and Teacher Education: An International Journal of Research and Studies, 27(1), 3-9. doi: https://doi.org/10.1016/j.tate.2010.07.015

Bergem, O. K., Nilsen, T. \& Scherer, R. (2016). Undervisningskvalitet i matematikk. I O. K. Bergem, H. Kaarstein, \& T. Nilsen (Red.), Vi kan lykkes i realfag. Resultater og analyser fra TIMSS 2015 (s. 120-136). Oslo: Universitetsforlaget.

Boyd, D., Grossman, P., Lankford, H., Loeb, S. \& Wyckoff, J. (2005). How Changes in Entry Requirements Alter the Teacher Workforce and Affect Student Achievement. NBER Working Paper Series, 11844. doi: https://doi.org/10.1080/00313831.2012.72627410.3386/w11844

Breivik, L. M. \& Fosse, B. O. (2016). Lærerutdanning i det 21. århundre - tradisjoner, utfordringer, endringer. Acta Didactica Norge, 10(2), 1-10. doi: http://dx.doi.org/10.5617/adno.2875

Broemmel, A. D. (2006). No Teacher Left Behind: Valuing Teacher Voice in Elementary Reading Teacher Education Reform.(Author abstract)(Report). Reading Research and Instruction.

Cochran-Smith, M. \& Villegas, A. M. (2015). Framing Teacher Preparation Research: An Overview of the Field, Part 1. Journal of Teacher Education, 66(1), 7-20. doi:10.1177/0022487114549072

Cochran-Smith, M., Villegas, A. M., Abrams, L., Chavez-Moreno, L., Mills, T. \& Stern, R. (2015). Critiquing Teacher Preparation Research: An Overview of the Field, Part II. Journal of Teacher Education, 66(2), 109-121. doi: https://doi.org/10.1177/0022487114558268

Darling-Hammond, L. (2000). Teacher quality and student achievement: A review of state policy evidence. Education Policy Analysis Archives, 8, <xocs:firstpage xmlns:xocs="'/>.

Darling-Hammond, L. (2005). Powerful Teacher Education: Lessons from Exemplary Programs (Vol. 8). New York: New York : John Wiley \& Sons, Incorporated. 
Darling-Hammond, L. (2008). Knowledge for Teaching. What Do We Know? In M. CochranSmith, S. Feiman-Nemser, D. J. McIntyre, \& K. Demers (Eds.), Hanbook of Researchon Teacher Eduation: Enduring Questions in Changing Contexts (pp. 1316-1323). New York: Routledge.

Darling-Hammond, L. (2014). Strengthening Clinical Preparation: The Holy Grail of Teacher Education. Peabody Journal of Education, 89(4), 547-561. doi:10.1080/0161956X.2014.939009

Darling-Hammond, L. \& Youngs, P. (2002). Defining Highly Qualified Teachers: What Does Scientifically-Based Research Actually Tell Us? Educational Researcher, 31(9).

Driel, J. H. v., Berry, A. \& Meirink, J. (2014). Research on Science Teacher Knowledge. I N. G. Lederman \& S. K. Abell (Red.), Handbook of Research on Sciecne Education (Vol. II, s. 848-870). New York \& London: Routledge.

Engelien, K., Eriksen, T. M. \& Jakhelln, R. (2015). Integrerte studiedesign fir femårig lærerutdanning. I U. Rindal, A. Lund, \& R. Jakhelln (Red.), Veier til fremragende larerutdanning (s. 157-169). Oslo: Unversitetsforlaget.

Fischer, H. E., Borowski, A. \& Tepner, O. (2011). Professional Knowledge of Science Teachers. I B. J. Fraser, K. G. Tobin, \& C. J. McRobbie (Red.), Second International Handbook of Science Education (Vol. Springer International Handbooks of Education, s. 435-448): Springer Netherlands.

Gess-Newsome, J. (2015). A model of teacher professional knowledge and skill including PCK. New York: Routledge, Taylor \& Francis group.

Grossmann, P. M. (1990). A Tale of Two Hamlets. New York: Teachers Collage press.

Gustafsson, J. E. \& Nilsen, T. (2016). The Impact of School Climate and Teacher Quality on Mathematics Achievement: A Difference-in-Differences Approach. I T. Nilsen \& J.-E. Gustafsson (Red.), Teacher Quality, Instructional Quality and Student Outcomes: Relationships Across Countries, Cohorts and Time (Vol. 2, s. 81-95). Cham: Springer International Publishing, Cham.

Hammerness, K. (2013). Examining Features of Teacher Education in Norway. Scandinavian Journal of Educational Research, 57(4), 400-419. doi: https://doi.org/10.1080/00313831.2012.656285

Hammerness, K., Darling-Hammond, L., Brandsford, J., Grossman, P., Rust, F. \& Shulman, L. S. (2005). The Design of Teacher Education Programs. I L. Darling-Hammond \& J. Brandsford (Red.), Preparing Teachers for a Changing World. What Teachers Should Learn and Be Able to Do (s. 390-441). New York: Wiley.

Hansèn, S.-E., Sjöberg, J. \& Eilertsen, T. V. (2014). Finske reformideer i norsk lærerutdanningsdiskurs. I K. A. Røvik, T. V. Eilertsen, \& E. M. Furu (Red.), Reformideer i norsk skole. Spredning, oversettelse og implementering (s. 167-193). Oslo: Cappelen Damm Akademisk.

Harlen, W. (1997). Primary teachers' understanding in science and its impact in the classroom. Research in Science Education, 27(3), 323-337.

Hattie, J. (2012). Visible learning for teachers : maximizing impact on learning. London: Routledge.

Haug, P. (2008). Lærarutdanning i endring. Norsk pedagogisk tidsskrift, 92(2), 100-111.

Haug, P. (2010). Kvalifisering til læraryrket, s. 9-28. Oslo: Abstrakt, 2010.

Haugan, J. A. (2011). A systematic review of research regarding Norwegian general teacher education 2000-2010. Nordic Studies in Education, 31(04), 229-244.

Herold, F. \& Waring, M. (2017). Is Practical Subject Matter Knowledge Still Important? Examining the Siedentopian Perspective on the Role of Content Knowledge in Physical Education Teacher Education. Physical Education and Sport Pedagogy, 22(3), 231-245. doi: https://doi.org/10.1080/17408989.2016.1192592 
Hill, H. C., Rowan, B. \& Ball, D. L. (2005). Effects of Teachers' Mathematical Knowledge for Teaching on Student Achievement. American Educational Research Journal, 42(2), 371-406.

Hopmann, S. (2006). Lererutdannelsen i Norden - et internationalt perspektiv. Kristiansand: Høyskoleforlaget.

Kaarstein, H., Nilsen, T. \& Blömeke, S. (2016). Lærerkompetanse. I O. K. Bergem, H. Kaarstein, \& T. Nilsen (Red.), Vi kan lykkes i realfag. Resultater og analyser fra TIMSS 2015 (s. 97-119). Oslo: Universitetsforlaget.

Karlsen, S., Olufsen, M., Haugland, O. A. \& Thorvaldsen, S. (2017). Et tidlig gløtt inn i den nye norske lærerutdanningen. Uniped, 40(04), 299-311. https://doi:10.18261/issn.18938981-2017-04-03

Kind, V. (2009). Pedagogical Content Knowledge in Science Education: Perspectives and Potential for Progress. Studies in Science Education, 45(2), 169-204. doi:10.1080/03057260903142285

Korthagen, F. J. (2010). How teacher education can make a difference. Journal of Education for Teaching, 36(4), 407-423. doi: https://doi.org/10.1080/02607476.2010.513854

Kunnskapsdepartementet. (2010). Forskrift om rammeplan for grunnskolelcrerutdanningen for 1. -7. trinn og 5. - 10- trinn. Oslo: Kunnskapsdepartementet.

Kunnskapsdepartementet. (2016a). Forskrift om rammeplan for grunnskolelærerutdanning for trinn 5-10. Oslo: Kunnskapsdepartementet.

Kunnskapsdepartementet. (2016b). Forskrift om rammeplan for grunnskolelcrerutdanningen for trinn 1-7. Oslo: Kunnskapsdepartementet.

Kvale, S. (1997). Det kvalitaitive forskningsintervjuet. Oslo: Ad Notam Gyldendal.

Kvale, S. \& Brinkmann, S. (2015). Det kvalitative forskningsintervju (3 ed.). Oslo: Gyldendal akademisk.

Lai, L., Amdam, R. P., Martinsen, Ø. L. \& Juel, E. (1997). Strategisk kompetansestyring. Bergen-Sandviken: Fagbokforlaget.

Leine, A. (2006). Educating school teachers. The education school projects.

Magnusson, S., Krajcik, J. \& Borko, H. (1999). Nature, sources and development of pedagogical content knowledge for science teaching. I J. Gess-Newsome \& N. G. Lederman (Red.), Examing Pedagogical content knowledge. Dordrecht: Kluwer academic publishers.

McKenzie, P., Santiago, P., Sliwka, A. \& Hiroyuki, H. (2005). Teachers matter. Attracting, developing and retaining effective teachers. Paris.

Mohamed, Z., Valcke, M. \& De Wever, B. (2017). Are They Ready to Teach? Student Teachers' Readiness for the Job with Reference to Teacher Competence Frameworks. Journal of Education for Teaching: International Research and Pedagogy, 43(2), 151170. doi: https://doi.org/10.1080/02607476.2016.1257509

Monk, D. H. (1994). Subject area preparation of secondary mathematics and science teachers and student achievement. Economics of Education Review, 13(2), 125-145. doi: https://doi.org/10.1016/0272-7757(94)90003-5

Moore, R. (2003). Reexamining The Field Experiences Of Preservice Teachers. Journal of Teacher Education, 54(1), 31-42. doi: https://doi.org/10.1177/0022487102238656

Nilssen, V. \& Solheim, R. (2015). 'I see what I see from the theory I have read.' Student teachers learning through theory in practice. Journal of Education for Teaching, 41(4), 404-416. doi: https://doi.org/10.1080/02607476.2015.1080423

Nixon, R. S., Hill, K. M. \& Luft, J. A. (2017). Secondary Science Teachers' Subject Matter Knowledge Development Across the First 5 Years. Journal of Science Teacher Education, 28(7), 574-589. doi: https://doi.org/10.1080/1046560X.2017.1388086 
NOKUT. (2006). Evaluering av allmennlererutdanningen i Norge 2006: Del 1: Hovedrapport. Oslo.

Olufsen, M., Karlsen, S., Andreassen, M. \& Sortland, A., B. (2015). Norske masterutdanninger i naturfag for grunnskolelærere - store variasjoner i omfang på masteroppgaver og fagsammensetning. Nordic Studies in Science Education, 11(3), 293303.

Olufsen, M., Karlsen, S., Sæleset, J. \& Thorvaldsen, S. (2019). Subject matter knowledge - A key component to increase the quality of the field placement. Ikke publisert.

Olufsen, M., Karlsen, S. \& Ødegaard, M. (2017). Endringer i lærerstudenters kompetanser? En casestudie fra en ny lærerutdanning ved UiT Norges arktiske universitet. Nordic Studies in Science Education, 13(2), 117-133.

Rasmussen, J. (2008). Nordic teacher education programmes in a period of transition: The end of a well-established and long tradition of 'seminarium'-based education? I Hudson B. \& P. Zgaga (Red.), Teacher education policy in Europe: A voice of higher education institutions (sas such. 325-344). Umeå, Sweden: University of Umeå, Faculty of Teacher Education.

Schneider, R. M. \& Plasman, K. (2011). Science Teacher Learning Progressions. Review of Educational Research, 81(4), 530-565. doi:10.3102/0034654311423382

Schreiner, C., Henriksen, E. K., Sjaastad, J., Jensen, F. \& Løken, M. (2010). Vilje-con-valg: Valg og bortvalg av realfag i høyere utdanning. Kimen, 2.

Shulman, L. S. (1986). Those who understand: Knowledge growth in teaching. Educational Researcher, 15, 4-14.

Sorge, S., Kröger, J., Petersen, S. \& Neumann, K. (2017). Structure and development of preservice physics teachers’ professional knowledge. International Journal of Science Education, 1-28. doi:10.1080/09500693.2017.1346326

Thagaard, T. (2013). Systematikk og innlevelse : en innføring i kvalitativ metode (4. utg. ed.). Bergen: Fagbokforl.

Tolo, A. (2017). Ulike perspektiver på hva kompetanse er. In A. Tolo (Ed.), Kompetnase og lærerprofesjonalitet (pp. 47-71). Bergen: Fagbokforlaget.

UiT. (2016). Ekstern evaluering av pilot i nord. Integrert masterprogram for grunnskolelcerere trinn 5-10 (IMA-LU 5-10). . Retrieved from Upublisert:

UiT. (2017a). Studieplan for integrert mastergradsprogram - lærerutdanning 5.-10. trinn. Hentet fra https://www.uit.no/Content/511020/cache=20171810104737/Studieplanmaster-i-1\%C3\%A6rerutdanning-5-10-trinn-h\%C3\%B8st-2017-kull-2013-2016-.pdf

UiT. (2017b). Studieprogram for integrert mastergradsprogram - lærerutdanning 1.-7. trinn. Hentet fra https://www.uit.no/Content/511058/cache=20171710141119/StudieplanMaster-i-1\%C3\%A6rerutdanning-1-7-trinn-h\%C3\%B8st-2017-kull-2013-2016-.pdf

Ulvik, M., Helleve, I. \& Smith, K. (2017). What and how student teachers learn during their practicum as a foundation for further professional development. Professional Development in Education, 1-12. doi:10.1080/19415257.2017.1388271

Wayne, A. J. \& Youngs, P. (2003). Teacher Characteristics and Student Achievement Gains. Review of Educational Research, 73(1), 89-122. doi:10.3102/00346543073001089

Weinert, F. E. (2001). Concept of competence: A Conceptual Calification. In D. S. Rychen \& L. H. Salganik (Eds.), Defining and Selecting Key Competencies (pp. 45-65). Seatle, Toronto, Bern, Gøttingen: Hogrefe \& Huber Publishers.

Wilson, S. M., Floden, R. E. \& Ferrini-Mundy, J. (2001). Teacher preparation research: Current knowledge, gaps, and recommendations (document R-01-3). In J. Res. Math. Educ. (Vol. 32, pp. 520-521). 
Vedlegg 1: Sammenligning av innholdet i PEL-faget for 1-4 år for 1-7 og 5-10 utdanningene. Felles innhold er markert i svart, innhold kun på 1-7 utdanningen er i rødt mens innhold kun på 5-10 utdanningen er i blått.

\begin{tabular}{|c|c|c|}
\hline & 1-7 utdanningen & 5-10 Utdanningen \\
\hline 1. år & $\begin{array}{l}\text { PFF-1010 Fra plan til praksis (30 } \\
\text { stp) } \\
\text { - } \quad \text { skolens samfunnsmandat i } \\
\text { form av opplæringslov og } \\
\text { læreplaner } \\
\text { - } \quad \text { yrkesetiske og profesjonelle } \\
\text { krav til læreren med særlig } \\
\text { henblikk på forholdet mellom } \\
\text { elev og lærer. } \\
\text { - } \quad \text { utvikling av grunnleggende } \\
\text { didaktisk kompetanse } \\
\text { - } \quad \text { tilpasset undervisning } \\
\text { - læringsmiljø }\end{array}$ & $\begin{array}{l}\text { PFF-1002 Ex paed (10 stp) } \\
\text { - } \quad \text { skolens samfunnsmandat i } \\
\text { form av opplæringslov og } \\
\text { læreplaner } \\
\text { - } \quad \text { yrkesetiske og profesjonelle } \\
\text { krav til læreren med særlig } \\
\text { henblikk på forholdet mellom } \\
\text { elev og lærer. } \\
\text { - pedagogikkfagets funksjon i } \\
\text { lærerutdanningen } \\
\text { fagdidaktisk tenkning og } \\
\text { arbeid i lys av læreplaner }\end{array}$ \\
\hline 2. år & $\begin{array}{l}\text { LRU-1001 (20 stp): } \AA \text { A mestre } \\
\text { mangfoldet } \\
\text { - } \quad \text { utvidet didaktisk refleksjon } \\
\text { knyttet til det individuelle, } \\
\text { sosiale og kulturelle } \\
\text { mangfoldet i elevgruppen } \\
\text { - } \quad \text { praktisk og metodisk kunnskap } \\
\text { i klasseledelse som setter } \\
\text { studenten i stand til å } \\
\text { gjennomføre tilpasset } \\
\text { opplæring i en gruppe/klasse } \\
\text { - utvikling av vurderingskriterier } \\
\text { og veiledning av elevene i } \\
\text { læringsprosessen } \\
\text { - refleksjon over ulike sider ved } \\
\text { egen relasjonskompetanse }\end{array}$ & $\begin{array}{l}\text { LRU-1550 (20 stp): Den } \\
\text { profesjonelle lærer og skolens } \\
\text { mangfold } \\
\text { • } \quad \text { utvidet didaktisk refleksjon } \\
\text { knyttet til det individuelle, } \\
\text { sosiale og kulturelle } \\
\text { mangfoldet i elevgruppen } \\
\text { - } \text { praktisk og metodisk kunnskap } \\
\text { i klasseledelse som setter } \\
\text { studenten i stand til å } \\
\text { gjennomføre tilpasset } \\
\text { opplæring i en gruppe/klasse } \\
\text { veiledning av elevene i } \\
\text { læringsprosesser og bruk av } \\
\text { formativ vurdering til å } \\
\text { målrette arbeidet med fagene } \\
\text { faglig refleksjon over egen } \\
\text { relasjonskompetanse og } \\
\text { didaktiske spørsmål knyttet til } \\
\text { utvikling og læring av } \\
\text { grunnleggende ferdigheter } \\
\end{array}$ \\
\hline 3. år & $\begin{array}{l}\text { LRU-2000 Skolen som lærende } \\
\text { organisasjon 1.-7. trinn (20 stp) } \\
\text { - } \quad \text { samarbeid med kollegaer, } \\
\text { ledelse, foreldre og andre som } \\
\text { inngår i skolens virksomhet } \\
\text { - } \quad \text { yrkesetisk bevissthet knyttet til } \\
\text { rollen som } \\
\text { organisasjonsmedlem og } \\
\text { lærerrollen mer generelt, }\end{array}$ & $\begin{array}{l}\text { LRU-2550 Skolen som lærende } \\
\text { organisasjon 5-10. trinn (10 stp) } \\
\text { - } \quad \text { samarbeid med kollegaer, } \\
\text { ledelse, foreldre og andre som } \\
\text { inngår i skolens virksomhet } \\
\text { - } \quad \text { yrkesetisk bevissthet knyttet til } \\
\text { rollen som } \\
\text { organisasjonsmedlem og } \\
\text { lærerrollen mer generelt }\end{array}$ \\
\hline
\end{tabular}




\begin{tabular}{|c|c|c|}
\hline & $\begin{array}{l}\text { inkludert normer for } \\
\text { informasjonsforvaltning } \\
\text { - } \text { skole og lærerarbeid i et mer } \\
\text { overordnet institusjonelt, } \\
\text { samfunnsmessig og kulturelt } \\
\text { perspektiv } \\
\end{array}$ & $\begin{array}{l}\text { - skole og lærerarbeid i et mer } \\
\text { overordnet institusjonelt, } \\
\text { samfunnsmessig og kulturelt } \\
\text { perspektiv }\end{array}$ \\
\hline 4. år & $\begin{array}{l}\text { LRU-3000 Skole, samfunn og kultur } \\
\text { (20 stp) } \\
\text { - } \quad \text { refleksjon over den instituerte } \\
\text { oppdragelsespraksis, inkludert } \\
\text { kulturpedagogiske sider ved } \\
\text { egen praksis } \\
\text { - } \\
\text { skolens kontaktflate med } \\
\text { samfunnet, både som sted og } \\
\text { på ulike regionale } \\
\text { nettverksnivå } \\
\text { et skoleprosjekt hvor utøvelse } \\
\text { av entreprenørskap er en viktig } \\
\text { drivkraft }\end{array}$ & $\begin{array}{l}\text { LRU-3550 Didaktikk, samfunn, } \\
\text { kultur (10 stp) } \\
\text { • } \quad \text { refleksjon over den instituerte } \\
\text { fagdidaktiske praksis, inkludert } \\
\text { kulturpedagogiske sider ved } \\
\text { egen praksis } \\
\text { - } \quad \text { utvikling av skolens } \\
\text { kontaktflate med samfunnet, } \\
\text { både som sted og på ulike } \\
\text { regionale nettverksnivå } \\
\text { fagdidaktiske muligheter og } \\
\text { begrensninger i lys av } \\
\text { kontekstvariasjon } \\
\text { elevens læring som en } \\
\text { relasjonell prestasjon } \\
\text { LRU-3551 Ungdom, kultur og } \\
\text { identitet (10stp) } \\
\text { barn og ungdoms identitets- } \\
\text { utvikling } \\
\text { handlingsrettet kompetanse for } \\
\text { å møte og legge til rette for } \\
\text { læring, medvirkning og } \\
\text { utvikling }\end{array}$ \\
\hline 5. år & $\begin{array}{l}\text { Masteroppgave i profesjonsfag } \\
\text { (30stp) }\end{array}$ & Fagdidaktisk masteroppgave (30stp) \\
\hline
\end{tabular}

